UC-NRLF

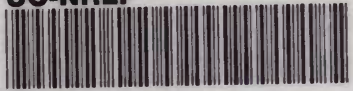

B 3319896 

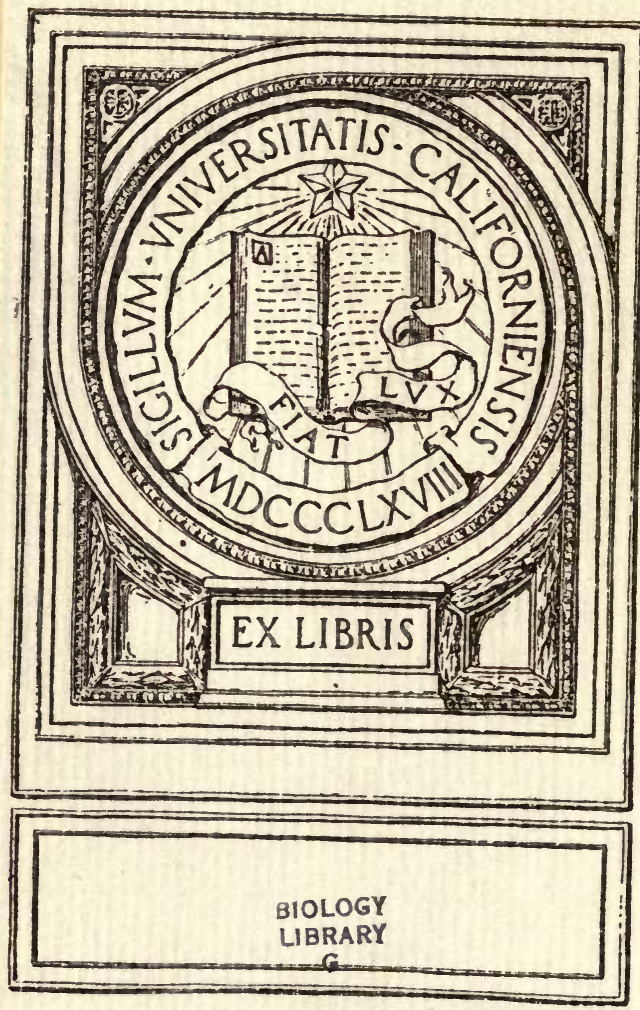


THE BIRDS OF RAINHAM. 


\section{NOT ES}

ON THE

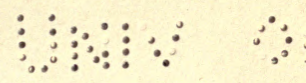

$\therefore \therefore \because \because \because \because$

\section{BIRDS OF RAINHAM}

INCLUDING THE

District between Chatham and Sittingbourne

WALTER PRENTIS

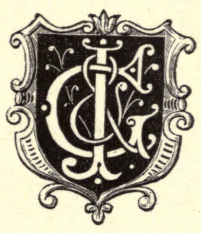

LONDON

GURNEY \& JACKSON, I, PATERnOSTER ROW (SUCCESSORS TO Mr. VAN VOORST)

MDCCCXCIV. 



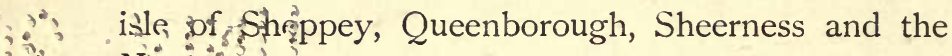
Nơrê.

$\because \because$ ooling north-east you will behold the mouth of the Medway; the isle of Grain, and on a clear day Southend in Essex. Turning to the north you will observe more diversified scenery, the busy haunts of man directly in front of you in the London Chatham and Dover railway, a mile of modern brick-built houses, the railway-station leading the way, a little further on you will perceive some ploughed fields, brick fields, a cement factory, orchards and marsh; lying between two creeks in the distance is a high bank of fine sand which must have been thrown up by the water at the last formation of the earth's surface; again extending your view, is the river Medway with its numerous craft, the land further beyond is the hundred of Hoo.

Again looking in the direction of north-west you will see in the distance the beacon-tower of Gillingham Church; beyond, on the opposite side of the Medway, are the hills of Upnor, adjacent to the city of Rochester and the dock-yard of Chatham; turning round to the west and south there is no view beyond the woods, and the orchards three parts encircle the foot of the church.

The soil of Rainham is a good loam resting upon chalk, more or less deep where the chalk does not approach the surface, more or less thin near the woods where the soil is flinty. Brick-making has been carried on for some few years, there are three wharves at the terminus of two creeks which extend one mile from the Medway. Clay-digging upon the 
salt marshes is another trade for the purpose of making cement; barges sail to and from London and elsewhere loaded with bricks, coal, clay, hay, straw, and most other kinds of produce and manure; the latter is a great benefit to the parish in every way rendering the soil more productive. Cultivation is going on as well as it can be done, almost everything that is either sown or planted grows as a rule to an average perfection.

Rainham possesses 2000 acres of land containing a population of 3000 inhabitants, swarms with children, 700 of whom attend school ; this must be considered a thriving parish and cannot be said to stand last upon the list towards national prosperity. Were the people evenly distributed they would occupy every acre, fortunately for the naturalist they prefer not the woods on one side of the parish or the marshes on the other; they flock for the most part into the principal village on the high road in the centre of the parish, where the shops, school, church, and various other places of resort are situate; employment is provided for all who are disposed to work, either in field or factory, high, low, rich and poor alike.

I now come to the subject of my text-Notes on the Birds of Rainham including the district between Chatham and Sittingbourne.

That extremely wet summer of 1860 is my excuse, or rather my pleasure, for making birds a study. Generally at home on my farm in the country my opportunities have not been slight for bird observation, at the same time being fond of my gun with a 
predilection for natural history, I have followed the pursuit on my own and neighbouring farms including the district from the year I 860 to the year I894.

I do not know but that my little book may contribute something towards a future history of the birds of Kent.

RAINham, June, I894 


\section{THE}

\section{BIRDS OF RAINHAM.}

Sea EAGLe.

Haliaëtus albicilla (Linnæus).

A pair of Sea Eagles paid my district a visit in the month of November, I879, one of them while sitting upon an oak tree over a furze bank frequented by rabbits, soon fell a victim to a sportsman's gun, a fine large Eagle in mottled plumage and with a whitish tail :- Another eagle was soon afterwards seen flying about I 50 yards high over the district; throughout this very severe winter it was seen to frequent manure heaps, killed a rook caught in a trap, and fed chiefly upon the marsh hares, carrying them over the marsh walls where generally a good look out was kept; however, in course of time, a shepherd with a gun approached, when too near to be pleasant his gun happened to miss fire, the Eagle flew away and was no more seen. 


\section{OSPREY.}

\section{Pandion haliaëtus (Linn.).}

I had the pleasure of meeting with an Osprey sitting upon a post on the salting in the parish of Upchurch, adjoining Rainham ; it had been feeding upon a flounder and when shot at by myself and friends it escaped, taking a direct course up the river ; an Osprey was shot three days afterwards, according to the "Zoologist," at Uxbridge in Middlesex.

An Osprey was shot here by Mr. George Power about the year I 878 in September-the month when the Grey Mullets are plentiful ; it was seen sitting on the edge of a narrow piece of salting beside the marsh wall, over which it was shot; at the same time being mobbed by a flock of Peewits.

\section{PEREgRINE FALCON.}

Falco peregrinus, J. F. Gmelin.

There is seldom a year passes that one or more Peregrines are not seen flying over the Medway, they are chiefly young birds, a few adults are now and then obtained; according to my notes one of the latter to five of the former; it is a very interesting sight to witness a Peregrine Falcon in pursuit of a flock of Starlings, dashing amongst them in the air until one is singled out for prey. 


\section{Hовву.}

Falco subbuteo, Linn.

A pair of Hobbies in the year 1860 took possession of an old Magpie's nest on the top of a row of Elm trees standing in one of our lanes; they were supposed to be Sparrow-hawks, but that could not be owing to their long wings and powerful flight, they seem to have brought off their young in safety; I did not happen to see them at the time, but we were visited by Hobbies for two years afterwards.

In the month of June, I 864 a male Hobby was shot in a cherry orchard this side of Sittingbourne by the bird-scarer, and the female was seen.

\section{MERLIN.}

Falco cesalon, Gmel.

A few years ago our woods were frequented by Merlins, they always came to roost in the winter time at a quarter to four o'clock, somewhat later when the days got longer. I once observed five altogether sitting upon a small oak-tree standing by itself in a low coppice; a pair continued to frequent the wood for some years afterwards, coming in to roost at the usual time, the female always before settling down to roost for the night took her station on the top of an elevated perch where a good look out was kept; the male at the same time keeping well out of sight amongst the thick high coppice. When the month of 
April came round and just before their departure, I observed both of them sitting upon the same tree, one on each side of it.

\section{KESTREL.}

Falco tinnunculus, Linn.

The Kestrel I observe occasionally, they appear to be not so common as they should be, I believe the reason is, that owing to our "pop-gunners" in the winter time, the poor Kestrel flying rather high and always being in view, gets shot; they seem to take possession of an old Magpie's nest if possible, and to breed near the outside of a wood.

LESSER KESTREL.

Falco cenchris, Naumann.

The reader may wonder how I became acquainted with such a bird: my answer is, I saw one in the Museum at Dover. What I am writing is about another which I observed, exactly like it. The latter end of March, I882, a pair of Linnets appeared in my garden as usual; on the 3 rd of April I saw a lump of Linnet's feathers on my lawn, such as an inverted tea-cup would cover, which must have been done by some hawk. Having never seen the like before I was much puzzled, however on the Ioth of April a hawklike chatter came issuing from a cluster of elm-trees standing in the field beside my garden, when a beau- 
tiful little fellow with sharp-pointed wings flew nearly over my head, circling and wheeling some thirty-five yards high ; the sun shining brightly at the same time, I had a good view of its back, which was red, the bird stayed here for nearly a month and after being shot at, becoming wilder and wilder each day.

\section{SPARROW-HAWK. Accipiter nisus (Linn.).}

This, our most common hawk, makes its appearance in the autumn, staying with us, if not shot, throughout the winter; where the small birds congregate on the stubbles, there is often a female Sparrow-hawk in attendance, the little red males lying wait in the thickets for the chaffinches or any passing prey.

I once saw a female Sparrow-hawk flying away from a clump of larch fir-trees, carrying material to build her nest, with quite a little faggot in her claws.

An immature Sparrow-hawk was picked up dead by a neighbour beside her parlour-window, having flown at a canary in a cage.

\section{BUZZARD.}

Buteo vulgaris, Leach.

The year 1870, the time of the French and German war, was famous for being our Buzzard year; according to Mr. Charles Gordon of the Dover 
Museum 25 Buzzards were obtained in East Kent alone ; I have heard of others being obtained in West Kent, a pair was shot in my district.

The same year I happened to hear a great clamour overhead, on looking up I saw about a dozen Jackdaws mobbing a Buzzard, the day was very fine and warm; they pursued their course upwards higher and higher, at last the Jackdaws having succeeded in driving the Buzzard away tumbled down one after the other into their natural element, contented.

\section{ROUGH-LEGGED BUZZARD.}

Buteo lagopus (Gmel.).

A Rough-legged Buzzard was shot December 3 Ist I879, by a woodman in pursuit of Pigeons, on a wet misty day; it flew from one tree into another where it was killed. I observed another about the same time on our salt marshes.

HONEY-BUZZARD.

Pernis apivorus (Linn.).

A pair of Honey-Buzzards were shot here September I88I, both in immature plumage; one a deep chocolate colour, the other a spotted variety beautifully variegated with white. 


\section{MARSH-HARRIER. \\ Circus aruginosus (Linn.).}

A Marsh-Harrier was shot and obtained in our woods in June I867, of a deep chocolate colour, head included, just beginning its moult.

\section{HEN-HARRIER.}

\section{Circus cyaneus (Linn.).}

Females are not uncommon in the autumn time of the year frequenting our woods, where they are sometimes met with and shot; the old grey males are seldom or never seen.

I once, when driving in the month of August, had the pleasure of seeing a pair, an old grey male and brown female, circling round the centre of a field of barley adjoining our main road.

Ash-Coloured or Montagu's Harrier.

Circus cineraceus (Montagu).

The Ash-Coloured Harriers, when they arrive, always come to us in the spring of the year, unlike the Hen-Harriers, which always come in the autumn; they at once take up their quarters in the woods, flying over the fields and low coppices, till they are shot, they seem to vary much in plumage ; the name Ash-Coloured applies to the old male with 
black bar across its wings; 6 varieties have been obtained in my district.

No. I. Old male with a black bar across wings.

No. 2. Old female dressed in shades of brown.

No. 3. Immature male, ash coloured with some light brown feathers intermixed.

No. 4. A dark coloured variety, chocolate, almost black.

No. 5. Dark chocolate mixed with brown.

No. 6. Light brown on the back, on the breast white slightly tinged with red.

Perhaps it may be of interest to note the date of each occurrence.

No. I. June 8, I $866 . \quad$ No. 4. May I8, I 867.

No. 2. May I7, i $869 . \quad$ No. 5. July , I 870.

No. 3. May I 5, I866. No. 6. May, i 888.

\section{LONG-EARED OWL. \\ Asio otus (Linn.).}

Not so common with us as the next to be described, they are shot in our woods occasionally, and on one occasion when hunting with beagles several flew from a leafy oak. I have never heard of their breeding in my district, we have no fir plantations.

\section{Short-EAREd OwL. Asio accipitrinus (Pallas).}

Not uncommon, comes in the autumn, visits our salt-marshes where they are shot nearly every year. 
When partridge shooting I have met with them in our turnip fields ; on one occasion a pair nested and succeeded in hatching their young on an island marsh which had been lying idle throughout the winter and spring.

\section{BARN OWL.}

Strix flammea, Linn.

This most useful bird, I am sorry to say, is a victim to persecution by every pop-gunner in the parish on coming, as it sometimes does. Its life after visiting our stacks once or twice is sure to be sacrificed. I have known a pair to breed more than once in our church roof, but this was a few years ago.

\section{Great Grey Shrike.}

Lanius excubitor, Linn.

The Great Grey Shrike has been observed and shot in my district at least three times.

I had the pleasure on one occasion of observing a Shrike on the top of a faggot stack in a wood; it was a brown bird, not unlike a Thrush, but when it flew off it settled upon the tops of the high spray and litters round an adjoining wood where I followed it; I had no difficulty in identifying the bird, especially when it hovered like a Kestrel over a grassy lea. Could it have been a young bird? if so it was very wild. Yarrell does not speak of such a variety, neither do other ornithologists. 


\section{RED-BACKED SHRIKE.}

\section{Lanius collurio, Linn.}

Comes to us the latter end of April or the beginning of May, is not uncommon and breeds if not disturbed, as a rule in thick thorn bushes on the borders of pastures where beetles and other insects abound, but this is not always constant; I once found their nest in a roadside hedge bordering a ploughed field ; pastures were close at hand.

\section{W OODCHAT SHRIKE.}

Lanius rutilus, Latham.

One was shot May 7, I868, not exactly in my district, in an orchard; in its crop, as I was informed, was a bee, some caterpillars, and two pieces of grit; it is a light coloured specimen, probably immature.

\section{Spotted Flycatcher. Muscicapa grisola, Linn.}

The Flycatcher comes to our homesteads and orchards when the apple trees are in blossom, stays with us throughout the summer doing all the service it can, leaves sometime in September; I, for one, wishing it a safe passage all the way to Africa and back again. 
Pied Flycatcher. Muscicapa atricapilla, Linn.

I have never once met with the Pied Flycatcher. One of a pair was shot in a wood-lane, by a small pond, May Ist, I87I.

\section{Missel Thrush.}

Turdus viscivorus, Linn.

A few mild days in February the Missel-Thrush begins to enliven us with its song, being the first of the Thrushes to remind us of the time of the year ; builds the latter end of March, making its nest and laying its eggs in either an apple or pear tree in our orchards, but owing to the bare foliage is seldom allowed to rear its young; it never attempts to make a second nest near the same place.

The loud wild note of the "Storm Cock" is most engaging, as a rule indicative of rough stormy weather.

\section{SONG Thrush.}

Turdus musicus, Linn.

The Song thrush begins to warble forth its charming song the beginning of February, and enlivens us at bright intervals throughout the month; when spring time comes round the Thrush sings its wild, loud, melodious carol on an elevated perch from 
morning till night. They suffer much in severe weather which carries many off; no bird would be more missed than the Thrush; I have always, I am happy to say, one which has withstood the chills of winter left in my garden to sing through the spring and summer, and to share with me the fruits in my garden.

\section{FIELDFARE.}

Turdus pilaris, Linn.

Some winters uncommonly plentiful, others very scarce, this appears to depend on their immigration, north or south; I have known them some seasons to arrive in continuous flights, one after another, in the same direction all the day long, the last flight in the dusk of the evening coming in contact with the telegraph wires on our railway, where five were once picked up at the same time; they appear on this occasion to have come by way of the Isle of Sheppey, taking a line parallel with the creeks towards our lower orchards, and after topping them flying direct for the woods, where they turned towards the west into the country. Should they take a northern passage across the sea, we see but few throughout the winter. A cream coloured variety was shot December, 1878 .

\section{REDWING.}

Turdus iliacus, Linn.

Comes in the autumn, the latter end of October, in small numbers, feeds on our pasture land and in our 
orchards; when the snow lies on the ground they feed upon the hawthorn berries and on the manure heaps. Should the winter be severe they suffer equally with the Song Thrush.

\section{RING-OUZEL.}

Turdus torquatus, Linn.

The Ring-Ouzel passes through Rainham on its passage north in spring, south in the autumn, sometimes, when food is to be had, staying a few days with us. Always wild, choosing for its perch the tops of trees.

\section{BLACKBIRD.}

Turdus merula, Linn.

The Blackbird frequents our gardens all the year round, at no time does its jet black plumage shine with more lustre than when in mid-winter the snow is lying on the ground, associating with the sparrows and feeding where the poultry are fed.

\section{HEDGE SPARROW. Accentor modularis (Linn.).}

The Hedge Sparrow is another of our garden birds almost always to be seen on looking out of the window, picking up something on grass plots and gravel walks. 
ROBIN.

Erithacus rubecula (Linn.).

The familiar Robin makes itself at home everywhere.

NightiNGALE.

Daulias luscinia (Linn.).

Everybody knows the coming of the Nightingale, soon as springtime comes we are waiting for the great event of the year to hear our woods and hedges rattle with its glorious song; the middle of April is the time, nor does it lose a day or night after coming, if the weather is at all favourable, to pour forth at once its charming melody.

What would a country life be worth in the south of England without the far-famed Nightingale?

\section{REDSTART.}

Ruticilla phonicurus (Linn.).

The Redstart once was common in our orchards, coming the second or third week in April, now only to be heard and seldom seen on the outskirts of the woods, where it breeds in the old boundary stumps.

BLACK REDSTART.

Ruticilla titys (Scopoli).

When driving, October Ist, I865, I observed a 
Black Redstart with white on its wings, fly along a wire fence.

An immature Black Redstart was caught by a birdcatcher in one of our brickfields, Nov. I887.

\section{STONECHAT.}

\section{Saxicola rubicola (Linn.).}

The Stonechat is more common with us in winter than in summer. I have never heard of its breeding in my district, but it may possibly do so in some snug corner or other. We have no furze banks or rough commons, and it does not appear to approve of clean pastures and cultivated fields.

\section{WHINCHAT.}

Saxicola rubetra (Linn.).

Comes in April, probably breeds in my district more often than the Stonechat; a pair frequented a narrow coppice on my farm in I886. On mowing clover and making hay in the field adjoining, a nest was discovered containing four blue eggs, built on the ground, after the manner of the Skylark, the scythe cut clean over it; the hay-makers were puzzled, never having seen blue eggs in such a place before, at least fifty yards from the hedge. 


\section{WHEATEAR.}

Saxicolo cenanthe (Linn.).

The Wheatear, coming in March, is the first spring arrival which attracts our attention; more often seen on the marsh than on the plough land. I have noticed some few in summer time flitting along our marsh walls showing their conspicuous white tail coverts, probably breeding in the blocks of stone used for supporting the embankment.

\section{GRASSHOPPER-WARBLER. \\ Acrocephalus nevius (Boddaert).}

Some six years ago before the cold wet summers set in, our woods were alive with 'cricket birds,' their note could be heard on a summer evening in all directions ; in consequence of the cold and wet lasting year after year they have become scarce, and last year not a 'cricket bird' was" to be heard, they have, in fact totally disappeared.

A singular variety was obtained June 5th, I 869 , back greenish brown, with darker markings, breast greenish yellow without spots, a male, shot singing.

\section{SEDGE-WARBLER.}

Acrocephalus schonobanus (Linn.).

Comes in April, heard and seen in our marshes, frequents ditches which are overrun with brambles or 
any rough herbage; this is generally the case where the ditches divide the marshes from the plough land.

\section{REED-WARBLER.}

\section{Acrocephalus streperus (Vieillot).}

The Reed-warbler, as its name implies, is never met with as a rule beyond the reach of a spot where reeds grow ; they seem to know the time when the reeds afford them shelter and protection in May. I have a specimen of the Marsh-Warbler-if the distinction is a broader bill than that of the Reed-warbler-which was shot in a garden beside a reed bed at Milton, May 1866.

\section{BLACKCAP-WARBLER.}

\section{Sylvia atricapilla (Linn.).}

The merry Blackcap comes in spring rather earlier than the Nightingale, leading the way and preparing us for the advent of its superior rival ; at the same time the note of the Blackcap is one among the many Warblers that come afterwards, and stands next to the Nightingale. He frequents our gardens, sings close to our doors directly on coming, making us at once acquainted with his presence.

\section{GARDEN WARBLER.}

Sylvia salicaria (Linn.).

The Garden Warbler was frequent in our gardens before the setting in of the cold wet summers, since 
which time they have been just as scarce as they were plentiful. I now hear only here and there one in our coppices and woods.

\section{WHITETHROAT.}

\section{Sylvia rufa (Bodd.).}

The Whitethroat is, perhaps, the most common of all our summer warblers, comes as a rule the third week in April, frequents the roadside hedges, constructs a thin flimsy nest made of the cleavers or goosegrass a foot from the ground, utters a merry, cheerful note, is provincially called jolly Whitethroat.

\section{LESSER WHITETHROAT. \\ Sylvia curruca (Linn.).}

Not very numerous as a species. A pair almost always come and sing near my dwelling when the apple trees are in bloom, sometimes breed in the garden shrubs.

\section{WOOD-WARBLER.}

Phylloscopus sibilatrix (Bechstein).

The Wood-Warbler is seen on passage ; our woods, being cut down every few years for the sake of the hop poles, do not appear to be adapted to their nature. 


\section{WILLOW-WARBLER. \\ Phylloscopus trochilus (Linn.).}

The Willow-Warbler ere the setting in of our wet summers, was very numerous, as a species no bird excepting the Grasshopper-Warbler seems to have suffered more from that cause; still we have a few left, which can be heard in our woods. Surely it must take several years of warm weather to recruit the ranks of our summer Warblers.

\section{CHIFFCHAFF.}

\section{Phylloscopus collybita (Vieill.).}

The Chiffchaff comes into our woods early, sometimes before the buds have burst into leaf, where its wellknown chiffchaff note wakes us up, being the first messenger of spring's glad tidings for the future, should the summer prove acceptable to vegetation and to bird life.

\section{GOLDEN-CRESTED WREN.}

Regulus cristatus, Koch.

I have not seen the Golden-Crested Wren for several years, what has become of them I do not know, unless they have been affected by the cold and wet summers. On one occasion a pair built their nest in an Irish Yew tree in my garden. 


\section{Fire-Crested Wren.}

\section{Regulus ignicapillus (Brehm.).}

My first acquaintance with the Fire-Crested Wren was when I first thought of making a small collection of birds. In that wet year 1860 , anxious to obtain a Goldcrest, I thought I saw one in an apple tree beside my house ; on picking the bird up, to my delight, it was a female Fire-Crest. Date of occurrence, December, I860. Since, I have once met with a pair in the month of October on some larch firs.

\section{GREAT Tit.}

Parus major, Linn.

I observe these sprightly little birds in small parties when the woods have shed their leaves. When the foliage is thick they are scarce, we have no old timber trees for them to nest in. They do not breed in our orchards.

\section{Blue Tit.}

Parus ceruleus, Linn.

In winter the Blue Tit does not appear to be so numerous as the Great Tit. In summer they are at home near our dwellings, and are with the rest of the Tits examples of industry, never idle from morning till 
night, searching the twigs in every direction for insect food, which they entirely depend upon for subsistence.

\section{Cole-Tit. \\ Parus ater, Linn.}

I meet with the Cole Tit but rarely, perhaps one in the course of a year; they are always the continental variety. There are no fir plantations in my district to harbour the common species.

\section{MARSH Tit. \\ Parus palustris, Linn.}

I scarcely ever meet with the Marsh Tit in the marsh. They breed in the low stubs in our woods, and in winter time when the snow is on the ground, I observe them feeding among the horse-droppings in the roads by the woods.

\section{LONG-TAILED Tit. \\ Acredula caudata (Linn.).}

The Long-tailed Tits, like some of the warblers, have become very scarce. I seldom meet with them now. Before the wet and cold summers set in they were plentiful, building their beautiful domed nests in our woods. 


\section{BEARDED TIT. \\ Panurus biarmicus (Linn.).}

The Bearded Tit has not, to my knowledge, occurred in my district. Three were shot in a reed bed on the banks of the Medway in the winter of I 865, near Maidstone.

\section{WAXWING.}

Ampelis garrulus, Linn.

The Waxwing is extremely rare in this district, only two to my knowledge have been obtained; one was shot from a pair in our woods in 1867 , another obtained in an orchard the same year. A small flight was seen in an orchard at Milton, taking a contrary direction from here where one or two others were obtained.

\section{Pied Wagtail. \\ Motacilla lugubris, Temminck.}

The neat chaste Wagtails keep us company all the year round, being most numerous in the autumn. They visit our sheep-folds in the winter, running among the sheep while feeding on the turnips. In summer we see them following the plough, picking up the wire-worms in the furrows, going and coming with their bills quite full of them for several hours together, and continuing their good offices till the team leaves off work. 


\section{GREY WAGTAIL.}

\section{Motacilla sulphurea, Bechs.}

The Grey Wagtail does not to my knowledge breed in this district. I now and then meet with one or two in the winter time running along a fresh water rivulet or beside a marsh ditch.

\section{YELLOW WAGTAIL. \\ Motacilla Raii (Bonaparte).}

The Yellow Wagtail comes on the Ioth of April, sooner or later according to the weather; the first comers are always the most brilliant in plumage. After a day or two's stay they go north followed by others which are all young birds, and such we are obliged to make ourselves contented with ; they breed as a rule in our pea fields, not often in the clover.

\section{TREE-PIPIT.}

\section{Anthus trivialis (Linn.).}

The Tree-Pipit is one of our summer arrivals; comes in mid-April, frequents trees in our low coppices, whence circling upwards and returning to the same perch, sings in the air most sweet and delightful notes. When making hay near the woods the TreePipit flies from heap to heap keeping the haymakers company, singing all the while its pleasing song. 


\section{MEADOW-PIPIT. \\ Anthus pratensis (Linn.).}

The Meadow-Pipit is not very common in my district, more so in winter than in summer. We are without much rough herbage in spots on the meadows where they delight to frequent.

\section{Red-Throated Pipit. \\ Anthus cervinus (Pall.).}

I fell in with the Red-throated Pipit one fine sunshiny day at the beginning of the month of April, I880, flying up and down, singing and feeding along the ploughed furrows behind my plough while turning over a two years grassy lea. I was attracted by the bird being alone, and returned with my gun and shot it. On picking it up I thought it could be nothing more that a bright example of the Meadowpipit. Fortunately, I sent it to Mr. Gordon of the Dover museum to be preserved.

\section{Rock PIPIT. \\ Anthus obscurus (Lath.).}

The Rock-Pipit is common in winter along the shores of our creeks, picking up something on the edge of the water as the tide recedes from the shore; does not occur in summer time. 
I once had the pleasure of meeting with the Vinous Pipet (Anthus rupestris) one rough March, the wind blowing for several days from the east the marsh was full of rock Pipits ; I observed a strange looking variety with a reddish-brown breast, sitting upon a barway; its note, on being disturbed, was very different from the Rock-Pipit's.

\section{RICHARD'S PIPIT.}

\section{Anthus Richardi, Vieill.}

I have only upon one occasion had the pleasure of meeting with Richard's Pipit. I observed a longtailed lark sitting on a gate in an island marsh when the tide had covered the saltings, it flew from off the gate to underneath a lump of deal plank which had been used for repairing the marsh wall, from thence into a cabbage garden and out of sight beside a pen of sheep. Surely, Richard's Pipit must be a very creeping bird.

\section{SKYLARK.}

Alauda arvensis, Linn.

The Skylark is everywhere plentiful. The first fine day or two in February he begins to sing, never failing to do so all the year except in rough weather and moulting time; just before a thick fall of snow they migrate, but return again soon after a thaw. 


\section{WOODLARK.}

\section{Alauda arborea, Linn.}

The only time I have met with the Woodlark was when the labourers were throwing out the heaps of manure in winter, when the snow lay thick on the ground and the woods were covered with ice ; its note attracted my attention; others have occurred at the same season of the year.

\section{Snow-Bunting. \\ Plectrophanes nivalis (Linn.).}

The Snow-Bunting come in flocks about November and December; they appear to be young birds generally, probably some females amongst them; the old males seem to come more singly, they mix with the skylarks and are known by their white plumage.

CORn-Bunting.

Emberiza miliaria, Linn.

The Corn-Bunting is spread over all the district, not very numerous as a species, generally to be met with on search being made, does not associate as a rule with other birds, breeds in the grass when the meadows are laid in for hay ; also in pea-fields, singing its well-known note on the top of a bush or fence. 


\section{BLACK-HEADED BUNTING.}

\section{Emberiza melanocephala (Scop.).}

This Bunting is almost if not entirely peculiar to the reeds, rushes and sedge in the marsh, where they are always to be found ; they build their nests in low bushes. I once saw one in some dead herbage thrown up by the tide.

\section{Yellow BUNTING.}

Emberiza citrinella, Linn.

The Yellow Bunting congregates with the Finches on the stubble fields in winter, and not till the hedges are well secured in leaf does the "Yellow-ammer" think of building its nest in a low bush or hedge-bank, oftentimes beside a public road. It flies from twig to twig, or often upon the telegraph wires in front of you as you walk, ride, or drive along the road.

\section{Cirl Bunting.}

\section{Emberiza cirlus, Linn.}

There is only one patch in my district where the Cirl Bunting is to be found, about a mile of trees and bushes bordering the marshes in the vicinity of two old decoy ponds ; I once found a nest containing eggs in an old dried up decoy pond, it was built on the 
ground amongst the dead stems of the reeds. I have heard their note in the thick foliage on the top of trees; they are sometimes caught by the birdcatchers in winter.

\section{ChaFfinch.}

Fringilla calebs, Linn.

Chaffinches having spent the autumn and the winter associated with other finches, feeding upon seeds on the stubble fields, and having paired, return in the spring with their merry note and shining plumage, building their beautifully constructed nests among the apple-blossoms in our orchards.

\section{BRAMBLE-FINCH.}

Fringilla montifringilla, Linn.

The Bramble-Finch is not very common in my district, not more than two or three being seen at the same time, generally mixed with the Chaffinches and other indigenous varieties on our stubbles, and known by their white tail coverts. I have on two occasions seen one from my window feeding with the sparrows ; they are fond of a newly-sown oat-field in the month of March, just before they take their departure to spend the summer in Norway. 


\section{House-SparRow.}

\section{Passer domesticus (Linn.).}

The bold hardy sparrows, no weather however severe affects them; they swarm round our stacks and farm buildings in the winter, and when the summer comes they no doubt pick up insects for their young, redeeming in a small measure their offences. Corn is the food of the sparrow, they will rob the poultry if they can, no time of year are they so mischievous as when the corn is approaching maturity before harvest; this is the sparrows' feast, they make the best use of it, they assemble together in flocks with their young, doing the farmer much damage almost without a cure; white and cream-coloured varieties are often met with.

\section{TREE-SPARROW. \\ Passer montanus (Linn.).}

The Tree-Sparrow is common in the autumn and winter, arrives in October and November, keeps company with the finches on the stubble fields and round the corn stacks. I have observed them in small flocks by themselves on the marsh walls and beside the stable doors; they do not appear to breed in my district, though a pair or two may possibly have done so. 
Greenfinch.

Coccothraustes chloris (Linn.).

The Greenfinch resorts to the stubble fields in autumn and winter, mixes freely with the Chaffinches and Yellow Buntings, Tree-Sparrows and Bramblings ; when the snow lies on the ground they visit the farm homesteads; after the snow is gone join company again in the fields. They are rather bold birds, a horse-hair springe is sure to catch them, in summer building in rough hedges; they are not so familiar as the Chaffinch and Yellow Bunting, but where the one is frequent the others are never far away.

\section{HAWFINCH.}

Coccothraustes vulgaris, Pall.

The Hawfinch is far from being an every day bird with us. On one occasion, in spring, I observed five busily feeding underneath some cherry trees in an orchard; and upon another occasion a pair nested and reared their young in a wood beside a small pond; single birds are sometimes met with.

\section{GOLDFinCH.}

Carduelis elegans, Stephens.

I do not always see a Goldfinch in the course of a year ; they seem to be getting more and more scarce. 
A few teasles sometimes grow in our low coppices, where they are perchance met with.

\section{SISKIN. \\ Carduelis spinus (Linn.).}

Only upon two occasions have I met with the Siskin. Our chalk district does not possess any fresh-water streams to encourage the growth of the alder, the seeds of which I believe to be the food of the Siskin in winter.

\section{African Whydah Finch.}

\section{Vidua.}

A Whydah Finch was shot here. With the exception of one long tail feather being shot asunder it was in perfect plumage; how it got into my district is difficult to say, it did not look like an escape.

\section{REDPOLL.}

\section{Linota rufescens (Vieill.).}

I have only met with a few solitary Redpolls feeding on rough herbage beside the roadside; as with the Siskin, the district is not adapted to their requirements. 


\section{LINNET.}

\section{Linota cannabina (Linn.).}

The Linnet is pretty generally distributed, fond of keeping their own company, are remarkably fond of turnip seed ; when it can be procured will live entirely upon it. They nest sometimes in low hedges and gardens, singing and cheering us with their sweet notes. Two white varieties have been obtained.

\section{TWITE.}

\section{Linota flavirostris (Linn.).}

The Twite comes to us in the autumn and winter, is always to be met with along our marsh walls, sometimes in hundreds, and feeds upon the seeds of the salt-water herbage.

\section{BULlFinCH.}

\section{Pyrrhula Europaa, Vieill.}

One of our most persecuted birds is the Bullinch ; they leave the woods in winter for the plantations where their note is imitated, and they are shot, scarcely a single one escaping. Further back in the woods, out of reach of the plantations, when game shooting, a few may be seen. 


\section{Crossbill.}

\section{Loxia curvirostra, Linn.}

Only upon one occasion in the space of more than thirty years have we been visited by Crossbills. On December Ioth, I868, a little family of about a dozen appeared in our nurseryman's garden, seen feeding on the berries of an Arbor Vitæ tree, in all shades of plumage, one red, three green, the rest various. On laying aside one of the females that was shot, contrary to the nature of things the body became quite dried up without turning in the least putrid.

\section{STARLING.}

\section{Sturnus vulgaris (Linn.).}

One of our most useful birds is the Starling. They follow the plough in summer with the pied wagtails, feeding on the wireworms ; they are fatal enemies to most of our noxious insects, they breed in holes of trees in our orchards, leaving them with their young just before the cherries get ripe, when they congregate in the marshes, and as the winter approaches vast numbers are seen together probing the turf for every grub they can find, leaving the marks of their bills thick on the grass in all directions. I once had the pleasure of seeing the Starlings leaving the marshes and going to roost; there must have been hundreds of thousands, strings of Starlings half a mile long following each other in rapid succession for more 
THE BIRDS OF RAINHAM.

than half an-hour; I wondered where they all came from. White varieties are seen every year.

The Rose-Coloured Starling.

$$
\text { Pastor roseus (Linn.). }
$$

It has not been obtained in my district. One was shot by a labouring man wide of Maidstone on the Tonbridge Road in the year 1863 .

\section{RAVEN.}

Corvus corax, Linn.

The Raven is by no means common, our shepherds proclaim eternal war against them.

\section{CROW.}

Corvus corone, Linn.

Crows are common enough, and frequent trees where they breed. They are great pilferers of eggs on the marsh, and destroy young birds; nothing seems to come amiss in the shape of plunder-" black as a Crow."

\section{Grey Crow.}

Corous cornix, Linn.

The Grey Crow comes in the autumn, feeds along shore, carries the Mussels and Cockles some height 
to drop them on the stone embankments by the river side, and if unbroken rises again with them. Is an indiscriminate feeder, mixes with the Rooks on the newly sown wheat, stays with us till the first week in April, and pecks out the eyes of the first lambs that fall before taking its departure for the north.

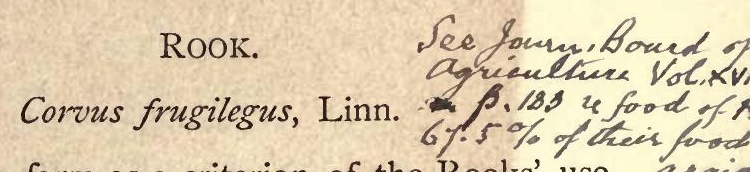

Taking my farm as a criterion of the Rooks' usefulness, throughout the summer I see but few, when I begin to sow the wheat in the autumn they come by thousands and continue doing so, off and on, throughout the winter, leaving soon after the barley is sown in the spring. Now if those persons who support a rookery, and where Rooks superabound were to feed them with several sacks of corn per day, they would then know the worth of the depredators they harbour and encourage.

\section{JACKDAW.}

Corvus monedula, Linn.

The Jackdaws in winter will sometimes associate with the Rooks, but are not such inveterate thieves, and will make themselves contented with the fresh laid out manure-heaps. I do not, as a rule, find them troublesome, Their breeding haunts are few in my 
district ; they used to nest in Rainham Church-tower before the windows were protected against them by wire blinds.

\section{MAGPIE. \\ Pica rustica (Scop.).}

Our woods afford a good supply of Magpies. They are not very numerous as a species, though constantly met with. I am inclined to think they are kept down by the foxes; I once saw where a Magpie had been buried by a fox, leaving the tip end of its tail in view. When the weather is rough they roost low, becoming an easy prey. The Magpie is a striking bird in our woodland scenery

\section{JAY.}

\section{Garrulus glandarius (Linn.).}

As our woods are not preserved, the Jays enjoy their own freedom, and keeping a good look out are seldom shot; a singular thing in their economy is that we always seem to have exactly the same number; it may be that the supply of food is limited, as our oak trees do not always produce acorns. The young broods appear to migrate, or perhaps like the Magpies are sometimes destroyed by foxes. I believe lately our regular number of Jays may have been interfered with by the cold wet summers. 
GREEN WOODPECKER.

Gecinus viridis (Linn.).

There are no park-like old timber trees in my district to encourage the breeding habits of the Green Woodpecker; in summer time we never see them, in autumn and winter a few, chiefly immature, get out of bounds and pay us a flying visit ; they are by no means common.

Great Spotted Woodpecker.

Picus major (Linn.).

The Great Spotted Woodpeckers, when they do occur, which is very rarely, invariably come in the month of October ; several have been obtained at that time of the year, old birds, both male and female.

\section{Lesser Spotted Woodpecker.}

\section{Picus minor (Linn.).}

The Lesser Spotted Woodpecker has been met with and obtained on several occasions in our lower orchards adjoining the marsh, a favourite locality both in the autumn and winter. Their appearance, like the Great Spotted Woodpecker's, is very uncertain; the fine black and white, striped and spotted plumage of each species has been seen, and their tapping of the trees heard with pleasure. 


\section{WRYNECK.}

Iynx torquilla, Linn.

The Wryneck or "Snakebird" wakes us up early in the spring with its peculiar note, even earlier than the Chiffchaff; the latter frequents the woods and coppices, the former our orchards and homesteads, and enlivens us at once with its familiar presence.

\section{Creeper.}

\section{Certhia familiaris, Linn.}

Though pretty generally distributed, the Creeper is not an every-day bird with us; we now and then catch a glimpse of one in our orchard trees, always climbing upwards from below; they do upon occasion nest in the old trees.

\section{WREN.}

Troglodytes parvulus, Koch.

The note of the Wren seems to be, for the bird's size, one of the loudest of our indigenous birds. Creeping amongst thick herbage, ivy covered walls, stumps of trees, examining every secure spot for insect food in the various stages of life, is fond of roosting in old thatch in cold weather, pulls straws out of the thatch, and frequents the same hole, if undisturbed, year after year. 


\section{HoOPOE.}

\section{Upupa epops, Linn.}

The Hoopoe has upon two occasions at least, been met with in my district, once in the spring of the year, and the other in the autumn, both times near trees on the border of the marsh. A third Hoopoe is said to have been seen this spring, I894. I have never had the pleasure of meeting with one myself.

\section{Nuthatch.}

Sitta casia, Wolf.

As in the case of the Green Woodpecker, we have no forest trees to encourage the Nuthatch. I have only twice seen it, on both occasions in the spring of the year in our orchards; I was attracted by the very peculiar note or sound which the bird made. Staying about a fortnight it kept repeating the same continuously, and meeting with no response flew away.

\section{Cuckoo.}

Cuculus canorus, Linn.

Everybody, when the time of year comes round, is on the look out for the Cuckoo ; they never are or can be deceived ; with us, as a rule, but not invariably, it comes three days after the Nightingale. They are thinly scattered in my district, a pair taking possession of some two miles of country which they appear to keep 
to themselves. Never was bird more welcome ; feeding chiefly upon various species of caterpillers, they seem to come and go with their favourite insect. I once found on brushing round some young trees after a wet night, a Cuckoo's egg in a half-built Yellow Bunting's nest ; the egg was stained with the soil of the field. I took it away, and in ten days the nest was finished and furnished with four Yellow Bunting's eggs. On another occasion I observed a young Cuckoo sitting upon almost nothing under the eaves of a haystack; it had been reared by a Robin, and had quite outgrown its compartment.

\section{KINGFISHER.}

\section{Alcedo ispida, Linn.}

When the Kingfishers appear in my district they come in the autumn and winter, visit the marsh dikes, sit upon a barway, stake or any other slight projection that commands a good view of the water, waiting for sticklebacks or other small fry upon which they feed; on being disturbed flying straight up the course of the ditch, showing conspicuously the brilliant colours which render the bird famous.

\section{ROLLER.}

Coracias garrulus, Linn.

A Roller was taken alive in our marsh on November 8th, I888. My people were employed clamping 
mangold wurtzel, when, to their surprise, a Roller came and settled upon the end of the range where they were at work, appearing unusually tame; they gave chase over the hedge, finally catching the bird, which had taken shelter on the leeward side of a lump of rushes ; the day was uncommonly cold ; the bird was in very thin condition, and died soon after it was caught; it had received a slight wound, and one primary was shot asunder.

\section{SWALLOW.}

Hirundo rustica, Linn.

The Swallow comes with the Cuckoo and Nightingale in the spring of the year, the one sometimes appearing before the other. We do not seem to have so many Swallows now as we used to have, the successive cold springs and wet summers have told very much against them ; according to my observation their numbers have been reduced by more than half. There was only one pair on my chimney-top last year instead of three, this may not be the case everywhere; no doubt with finer summers our insect loving birds will increase. The spring of the year I 869 was a very severe one for the swallows; on May 28th, I observed one lying dead beside my farm buildings and another flying more like a bat than a bird over my garden hedge ; others were seen by my brother, Mr. Edward Prentis, at his farm in the parish of Chalk near Gravesend with their heads under their wings for warmth, upon his horses' backs in the stable. 


\section{MARTIN. \\ Chelidon urbica (Linn.).}

The Martins come in the spring a few days after the Swallows, they are not numerous about here, we have no large colonies, a few scattered nests being all Rainham can boast of. The Martins' white upper tail coverts readily distinguish them from the swallows.

\section{SAND Martin.}

\section{Cotile riparia (Linn.).}

Like the Martin, this species forms no large colonies, as we have no sand banks to speak of. Here and there some spot may contain a nest or two. I once had the pleasure of seeing, though not in this district, about three hundred Sand Martins all in a line upon a field of young turnips, sitting and fluttering along devouring the fly and the turnip beetle.

\section{SwIFT.}

\section{Cypselus apus (Linn.)}

After the Swallow, the Martin, and the SandMartin comes the Swift; were these to start from Africa in a race the last-named would be first. They breed in our Church towers, exercising themselves in a body of a summer's evening, creaking and circling round the steeples till after sunset. They 
fly at a greater elevation than the Swallows, it may be they feed upon another kind of insect, for when the air, high and low, swarms with flies, they know their own respective boundaries.

\section{NightJAR.}

Caprimulgus Europous, Linn.

The Nightjar comes to us when our woods are getting into leaf and the moths are coming out, which is not before the middle of the month of May.

On a still summer's evening their rattling notes can be heard far away. They breed in our threeyears old coppice, choosing the driest spot they can find, under shelter with an open space above.

I am able to relate a most singular occurrence which happened to me on the 2Ist day of June, I869. When taking a walk at evening time and towards dusk, adjoining one of our Rainham woods, I had the pleasure of falling in with a chorus of notes, quite a novelty to me, lasting for about twenty minutes, when at nine o'clock, the music gradually ceased. It was as if all the Nightjars, Cuckoos and Cricket-birds in the district had assembled together for a premature and simultaneous departure. The dew was heavy and the wood struck very cold, so I wished them all good night and good-bye for the season; I did not hear or see any of them again. 
Ring Dove or Wood Pigeon.

Columba palumbus, Linn.

The Wood Pigeon with us is not numerous enough to be troublesome; it breeds in our woods sparingly, is most plentiful in winter, feeding upon the turniptops, where they are mostly met with and shot.

\section{STOCK Dove.}

Columba anas, Linn.

Small flights of Stock Doves are not uncommon, they too, like the Wood Pigeon, visit our turnip fields in winter, are more vigilant, and when keeping together are not easily approached. They sometimes breed in the old cherry trees in my orchards, never in the woods, are fond of an early sown pea field sheltered by the woods and will traverse every inch for a few surface scattered peas.

\section{Turtle Dove.}

\section{Turtur communis, Selby.}

The Turtle Dove as a rule comes not before the latter end of April, some years it is very plentiful. I have seen thirty or more together feeding on the turnip seed. They frequent the corn-fields where they feed upon the fumitory and other such like seeds. They breed in our woods and are common. 


\section{Pallas's Sand Grouse.}

\section{Syrrhaptes paradoxus (Pall.).}

The year I 863 was the first Sand-Grouse year, six were seen by a shepherd in the Vale of Elmley for several days near a patch of furze; ultimately a shepherd's boy with a gun came upon the scene, and two of them were shot, a male and female; this occurred on the seventh of June, they happened to come into my possession. Four Sand-Grouse were seen flying in a westerly direction two days afterwards, when another, a female, was shot by a gamekeeper.

The year I 888 was the second Sand-Grouse year, four were seen upon a ploughed field for several days in the parish of Hoo; on December the fourteenth a male was picked up dead, with head cut clean off by the telegraph wires on the Isle of Grain railway, another I believe was shot about the same time near Sheerness.

\section{Pheasant. \\ Phasianus colchicus (Linn.).}

Pheasants are more or less plentiful according as they are preserved.

PARTRIDGE.

Perdix cinerea, Lath.

The well-known, highly esteemed Partridge is generally distributed in the district. Our chalk soil 
with hill and valley, field and wood combined, makes excellent sport for the first of September.

A white or cream-coloured variety has been shot.

\section{RED-LEGGED PARTRIDGE.}

Caccabis rufa (Linn.).

The red-legged Partridge has spread within these few years all over my district; they are fine showylooking birds and in every way capable of taking care of themselves. Their habit of running before the dogs causes them to be of little use to the sportsman.

\section{QUAIL.}

Coturnix communis, Bonnaterre.

The Quail, when inclined to pay us a visit, always does so in the spring of the year, about the middle of May. Their loud clear notes are occasionally heard in our corn and clover fields, where they sometimes breed, they are not an everyday bird; several years may pass without one being heard or seen.

\section{Great or Norfolk Plover.}

Edicnemus scolopax (Gmel.).

The Great Plover must be considered scarce in the district ; one was shot December 23rd, I886, another 
in the month of March, 1892; one only has occurred to me upon a fallow field in the month of June. A few others have been met with.

Golden Plover.

Charadrius pluvialis, Linn.

November is the month for the Golden Plover, their arrival is most uncertain, some years they are tolerably plentiful, others very scarce. They frequent the plough fields, fly together in company of an evening over the low hedges, where they may be intercepted and shot. Should they not migrate until May, which sometimes does occur with a few, their black breasts are then conspicuous.

\section{DOTTEREL.}

\section{Charadrius morinellus (Linn.).}

Dotterels have occurred on the Isle of Elmley, May 3rd, I870, and again on May I9th, 1876. A young bird was obtained on the Isle of Sheppey, Sep. I 8th I864, all of them out of the bounds of my district.

\section{Ringed Plover. Agialitis hiaticula (Linn.).}

The Ringed Plover is the first river shore bird which I have to note. Owing to the great amount of 
traffic on the Medway they are somewhat thinly scattered but, notwithstanding the noise of vessels, our river flats are never without Ring Plover in the autumn and winter.

\section{Grey Plover.}

Squatarola helvetica (Linn.).

The Grey Plovers make their appearance on the Medway in the month of November, our sportsmen are then fully on the alert, and those which the vessels do not drive away generally fall into their pockets.

\section{PeEwit.}

Vanellus vulgaris, Bechs.

Our marshes are never without Peewits in the spring of the year, where they lay their eggs and sometimes breed; they flock together on our ploughed fields in the autumn, doing much good by feeding upon the snails and probably other insect pests, but I am sorry to say they are much persecuted.

\section{TURNSTONE.}

Strepsilas interpres (Linn.).

A few Turnstone Plovers come on the Medway in the autumn and are met with sparingly in winter; on one occasion a specimen was procured August i 892, in summer plumage. 


\section{Oyster Catcher. \\ Hamatopus ostralegus, Linn.}

The Oyster Catcher seldom comes on the Medway, there is a great deal too much traffic going on for them; a few appear singly and are sometimes shot.

\section{HERON. \\ Ardea cineria, Linn.}

Herons visit our marshes and the river Medway all the year round, most numerous in the autumn when the young are able to fly ; they come from a neighbouring heronry at Cobham, near Gravesend, where they are strictly preserved by the Earl of Darnley.

\section{Purple Heron. Ardea purpurea, Linn.}

An immature specimen of the Purple Heron was shot a few years ago in the vicinity of an old decoypond where some patches of reeds grow, near the Swale river.

\section{BITTERN.}

Botaurus stellaris (Linn.).

Our forty acres of spring marshes, where long thick herbage grows in the spring-water ditches 
adjoining some plantations, is a spot peculiarly adapted for the Bittern, and where they have been met with and shot upon at least four occasions; others also have occurred in the district.

\section{SPOONBILL:}

Platalea leucorodia, Linn.

A fine adult Spoonbill, with a buff collar and pendant crest, was shot on the Isle of Elmley, April I 2 th I 865 . Immature specimens have been met with on three occasions on the marshes near the river Medway.

\section{BLACK StORK. \\ Ciconia nigra (Linn.).}

In July I 884 a Black Stork was seen to visit an island marsh; the water in the ditches after some very dry weather became nearly dried up, leaving only a few puddles in places where the eels had collected; a trap was set by the shepherd, who instead of catching an eel caught the Black Stork, and nothing would do but that he must eat it. On July 24th, myself and Mr. Chas. Gordon, of the Dover Museum happened to be walking along a creek and when opposite the Shepherd's house we picked up the remains of a Black Stork, after it had floated backwards and forwards with the tide for some days, it was in a very mutilated condition, but 
we managed to secure the scull, feet and pinions as proof positive.

Another Black Stork was afterwards seen, and in all probability it shared a similar fate.

\section{CURlew.}

Numenius arquata (Linn.).

Curlews frequent our salt-marshes and mud-flats in considerable numbers, they make their appearance the latter end of August; our shooters lose no time in taking advantage of their arrival; with dogs for the purpose, they conceal themselves along shore, the Curlews, supposing the dog to be a fox, immediately give chase, uttering their peculiar cry and are shot. Some few Curlews remain with us throughout the summer, but they do not attempt to breed.

\section{WHIMBREL.}

\section{Numenius Phoopus (Linn.).}

The seventh day of May is the grand time for the Whimbrels. They are distributed singly on the edge of the river Medway, and by the side of every creek, following the tide as it recedes, returning with the tide when it flows, and after staying a week or ten days they are all off together, not a single one being left behind. In the autumn they make no stay, flying high overhead we hear their clear whistle. 
REDSHANK.

\section{Totanus calidris (Linn.).}

The Redshank is an old inhabitant of our saltmarsh and mud-flats, probably from time immemorial; there they constantly breed and rear their young. Owing, however, to the extended traffic on the Medway and the carrying away of the marsh clay for the purposes of cement, their numbers in the breeding-season are becoming gradually reduced; some few still favour us in the spring with their loud ringing call and roundabout flight, reminding us, wherever a piece of salt-marsh remains, of their close attachment to the spot.

\section{Spotted Redshank. \\ Totanus fuscus (Linn.).}

The Spotted Redshank pays our mud-flats a visit generally in the autumn. On one afternoon I met with a pair in the front of a snow-storm in midwinter. Young birds appear to be the rule, old birds the exception. The latter are met with occasionally.

Green Sandpiper.

\section{Totanus ochropus (Linn.).}

Common enough in the autumn about September and October. In that wet year, I860, a pair remained 
throughout the summer; they do not feed on our mud flats like most of the other Sandpipers, but appear to confine themselves to the marsh ditches, probably attracted by the small fry and insects that abound in such places. On being disturbed their rapid flight, white rumps and loud whistle enlivens the marsh.

WOOD SANDPIPER.

Totanus glareola (Gmel.).

It was after a storm of thunder and lightning and a tremendous heavy rain at night, which happened on the 26th July, 1867, that on the following day a flock of about one hundred Wood Sandpipers appeared in our marsh, five of them were shot, other single birds were afterwards met with.

\section{Common SANDPIPER.}

\section{Totanus hypoleucus (Linn.).}

More common on their return journey in the autumn than their forward northern journey in the spring, when their visits are few. In the former season they frequent our marsh ditches with the Green Sandpiper, but do not appear to associate with it. On being disturbed the latter flies high, the Common Sandpiper flies low along the water and round the bend of the ditches; their stay is not so prolonged as that of the Green Sandpiper. 
Avocet.

Recurvirostra avocetta, Linn.

The Avocet is extremely rare; only upon one occasion, to my knowledge, having been met with, which was on the 23 rd September, 1887 , one was seen flying along a creek and shot; a bird of the second year; another was observed soon afterwards, which I believe escaped.

\section{BlaCK-TAIled Godwit. \\ Limosa agocephala (Linn.).}

In the month of January, I88I, several immature Black-tailed Godwits were met with, flying along the edge of our Medway saltings at the flow of the tide, one of them was shot. October 20th, I 882. A pair of adult Black-tailed Godwits, accompanied with a pair of adult Spotted Redshanks, were together on the border of one of our Medway creeks ; one of each was shot.

\section{RUFF.}

\section{Machetes pugnax (Linn.).}

Adult Ruffs on their migratory passage are extremely rare; immature birds in the autumn are frequently obtained, they seem to prefer the marsh ditches to the more open banks of the Medway. 


\section{BAR-TAILED GODWIT. \\ Limosa lapponica (Linn.).}

A common autumn migrant, more numerous on the mud flats and the banks of the Medway some seasons than others. I have never known them to be seen on the spring passage in their red plumage, probably they take a direct course along the coast rather than coming inland.

\section{WoODCOCK.}

Scolopax rusticula, Linn.

This inestimable bird,- - general favourite with every sportsman,-is not very numerous as a species with us, our woods lying upon the chalk seem to be too dry for their requirements; still we are never without a few, and the most I have heard of being shot in a day is a brace. Some scattered single birds are all we can boast of. In the spring of the year it may be a few others are seen on passage, flying over the woods on the eve of their departure for the far north.

GREAT SNIPE.

Gallinago major (Gmel.).

Has not to my knowledge been met with, but I cannot help thinking that it must have occurred. 


\section{Common Snipe.}

\section{Gallinago calestis (Frenzel).}

The shooting of the Common Snipe, as proof of a sportman's skill is not practised here so often as could be wished. About half a dozen shots in a day is the most our dry marshes will afford ; they come and go, as every sportsman knows, here to-day and gone tomorrow, and often does it occur that when most expected they are never seen at all.

\section{JACK SNIPE. \\ Gallinago gallinula (Linn.).}

Our Rainham marsh usually contains in the winter season two or three Jack Snipes; they come, as a rule, the latter end of November. I once shot a "Jack" at the beginning of April in the plumage of glossy green.

CURlew SANDPIPER.

Tringa subarquata (Güldenstädt).

The Curlew Sandpipers come the beginning of September. They frequent the shores of our creeks in small numbers as a species, and are very tame. Once, while rowing a boat, a pair came and settled some five yards off me. They sometimes occur in the half changed plumage from summer to winter ; their stay is about a month. 


\section{KNOT.}

Tringa canutus, Linn.

Immature Knots visit our Medway mud flats in very small numbers in the autumn; half a dozen is the most I have met with at the same time together ; others are driven into our creeks in severe weather.

\section{LitTle Stint.}

Tringa minuta, Leisler.

The Little Stint is extremely rare as a species on the river Medway. A pair was obtained the 17 th day of September, I88I ; they were shot flying along a ditch on an island marsh, and another pair or two have been shot on the margins of our creeks.

\section{Temminck's Stint.}

\section{Tringa Temmincki, Leisl.}

Temminck's Stint has occurred on more than one occasion on our Rainham marsh. I once had the pleasure of shooting the bird, but this was outside my district, on the Isle of Sheppey; it was flying the opposite side of a wide ditch; I shouldered my gun thinking to shoot a Dunlin, and on pulling the trigger I observed the bird was smaller. I picked up a Temminck's Stint in winter plumage the Ist November, I869. 


\section{Dunlin.}

\section{Tringa variabilis, Linn.}

The Dunlin is more or less numerous on the banks of the Medway and mud-flats according to the severity of the season; I have seen them in fifties, in hundreds, and in thousands; they begin to make their appearance in August, when other shore birds, such as ringed Plovers, consort with them; I have shot them flying together with jet-black breasts ; we have a smaller variety which I have met with on the borders of our creeks in the month of April after all the rest of the Dunlins are gone, in red plumage and with less black on the breast, they appear to be a distinct race. I have not heard of their making any prolonged stay with us.

\section{PURPLE SANDPIPER.}

Tringa striata, Linn.

When the winter has been severe I have shot the Purple Sandpiper on our marsh walls, where they have been repaired with rock-stone.

\section{Red-NeCKed Phalarope.}

\section{Phalaropus hyperboreus (Linn.).}

A red-necked Phalarope has been obtained in the autumn time of the year on the Rainham marsh, 
another was shot swimming on the Isle of Elmley, November, I 867 , both immature.

Grey Phalarope.

Phalaropus lobatus (Linn.).

This neat, chaste, pretty bird does now and then pay us a visit, but their visits are few, only two or three to my knowledge have been obtained on the banks of the Medway in my district, others possibly may have occurred.

\section{LANDRAIL.}

Crex pratensis, Bechs.

September is our month for the Landrail; they resort to the clover-fields where the sportsman is pretty sure to find them. On one occasion, when all the young clover seeds failed to grow, I happened to leave my clover field for another year, being the only one in the neighbourhood, I shot twenty-five Landrails on nine acres in September, this was, however, a most unusual event; they commonly are met with singly, or at most in twos or threes. On one occasion I shot a Landrail in the month of December in a turnipfield.

\section{SPOTtED RAIL. \\ Poranza maruetta (Leach).}

Our Rainham marsh is not always without a Spotted-Rail ; when they appear it is in the autumn, 
generally in the month of October; several have been obtained and others from their creeping habits have, no doubt, passed unnoticed.

\section{WATER RAIL. \\ Rallus aquaticus (Linn.).}

Almost every winter our marsh ditches and spring water-courses contain a Water Rail or two, the sportsman in quest of Snipe meets with them, their laboured flight affords an easy shot.

\section{MOOR Hen.}

\section{Gallinula chloropus (Linn.).}

Having only a small extent of spring or fresh-water marsh at Rainham, the Moor Hen is not with us a very common resident; where thick herbage grows a pair or two take up their abode, and in the absence of persecution rear their young, they have been picked up dead on our railway, having flown against the telegraph wires on migratory passage.

\section{Соот.}

Fulica atra, Linn.

Seldom or never seen on our Rainham marshes. I know of only one instance of their being observed; 
a pair came, built a nest and laid an egg, which was immediately destroyed by a carrion crow, in a bunch of rushes near the outside of a broad piece of water, they took their departure and were no more seen. They sometimes occur on passage near woods and other out-of-the-way places.

\section{Wild Grey Geese and Wild Swans.}

Owing to the excessive traffic on the Medway from the constant sailing to and fro of vessels to the number of two hundred every day, the wild Grey Geese and Wild Swans have no resting place there. My acquaintance is limited to seeing them fly over at a considerable height in very severe weather, first to the south, afterwards back again to the north; merely their outline is visible.

Brent Goose.

Bernicla brenta (Pall.).

The Brent Geese come into our creeks in severe winters in very small numbers; no sooner do they appear than they speedily have notice to quit and are off, one or two are sometimes shot.

* I have had no means of identifying the species; they are either Geese or Swans. 


\section{BEWICK's SWAN. \\ Cygnus Berwicki, Yarrell.}

On January 22nd, I879, an excellent specimen of Bewick's Swan was shot in an extraordinary way. Some shooters were lying in wait for sea-gulls under the shelter of a wood, the gulls returning from the fields which had been manured with sprats, when a Swan came flying in the same direction, following the track of the Gulls at some height ; a number six shot happened to touch a wing, the bird immediately lowered, and dropped about a quarter of a mile off; it was pursued and captured.

\section{SHELDRAKE. \\ Tadorna cornuta (Gmel.).}

The Sheldrake comes into our river in severe winters, always leaving the broad water to the many vessels of trade; they drop like other fowl under the leeward side of a few sheltered spots in our creeks.

\section{SHOVELLER.}

\section{Spatula clypeata (Linn.).}

The noise and bustle on our river keeps nearly all the wild fowl away, the Shoveller does not appear to be one of those which will easily submit to it, they come and are off again; are very seldom shot. 


\section{GADWALL. \\ Anas strepera, Linn.}

The Gadwall taking a view of our numerous craft gives them a wide berth; are very seldom if ever shot.

\section{Pintail. \\ Dafila acuta (Linn.).}

The Pintail is much more common than the two preceding species. Scarcely a severe winter passes without a pair or two being shot on some of the creeks and salt marshes on the Medway.

GARGANY.

Querquedula circia (Linn.).

A pair of Garganys were shot on one of our island marshes on the 7 th day of March, I874, and three immature birds were shot on one of our creeks, August, I 893.

\section{WILD DUCK.}

Anas Boschas, Linn.

In severe winters after a strong breeze from the east, Wild Ducks in small numbers come into our creeks for shelter. A neighbouring proprietor has 
lately enclosed a wide extent of salt marsh, converting it by means of embankments into a pasture marsh for sheep, and from philanthropic motives has succeeded in establishing a pond in the centre for the preservation of Wild Duck; they separate and pair in March, are seen to frequent most of the adjacent marshes where they breed.

A note from me was published in the Zoologist, and copied into many local and other newspapers, as follows :-

"A mowing machine was set to work, June, r89r, round the outside of a field of lucerne bordering our marsh, diminishing the circle each time round the field, leaving about two acres in the centre. A Wild Duck was seen by the shepherd to fly from the piece of lucerne that was left with something in her beak, and happening to fly near him, she dropped a three parts incubated egg. She was observed by the shepherd and also by the sheep-shearer carrying another egg in her beak, this time over the marsh wall towards the saltings, and again she was seen, the third time, carrying an egg in her beak in the same direction. On the mowing machine going to work the next day, and finishing the field by mowing the last piece of lucerne, the Wild Duck's nest was discovered from which the eggs had been removed."

A Wild Duck has been met with transporting her newly-hatched brood upon her back across the Medway. 


\section{TEAL. \\ Querquedula crecca (Linn.).}

This pretty little Duck is not so numerous as we could wish, being very thinly distributed on our marshes; they are rather more plentiful of late, particularly in the vicinity of the duck-pond.

\section{WIGEON.}

\section{Mareca Penelope (Linn.).}

On the Medway are to be seen generally more vessels than birds; how then is it possible for Wigeons to gain a settlement for the shortest period? They come, are off again, perhaps even faster than they came; it must be a very severe winter for a few to drop on our creeks.

\section{EIDER DUCK.}

Somateria mollissima (Linn.).

A pair of Eider Ducks were shot on the Medway a few years ago in their immature brown plumage.

\section{VELVET SCOTER. Edemia fusca (Linn.).}

Velvet Scoters do sometimes appear on the Medway, for the most part either females or immature ; several have been shot. 


\section{COMMON SCOTER.}

\section{Edemia nigra (Linn.).}

The Common Scoter has not, to my knowledge, been shot on the Medway.

\section{POCHARD.}

\section{Fuligula ferina (Linn.).}

We have no harbour for the Pochard, come it does upon occasion and goes, like Wigeon, even faster than it comes. The incessant traffic on our river, which increases every year, bids fair to drive the Pochard right away.

\section{Scaup Duck.}

\section{Fuligula marila (Linn.).}

The Scaup Duck 'is certainly much less uncommon than the Pochard; at uncertain intervals, mostly in severe weather, our gunners obtain a few, as a rule chiefly single birds, numbers being quite the exception.

\section{TUFTED DuCK. \\ Fuligula cristata (Leach).}

The Tufted Duck is not uncommon. They come into the creeks and marshes for the most part singly, and always in winter time; are thinly distributed. 
LONG-TAILED DUCK.

Fuligula glacialis (Linn.).

Two examples of the Long-tailed Duck have come to my knowledge as shot on the Medway, both specimens immature, others probably may have been obtained.

Golden Eye.

\section{Clangula glaucion (Linn.).}

I know of but one instance of the mature Golden Eye being shot on our river; young birds are frequently shot, and on one occasion I saw a small flock of Golden Eyes, seven in number, one being almost white; on the first sign of danger they were off.

\section{SMEW.}

Mergus albellus, Linn.

Tuesday, the I8th day of January, I88I, will ever be remembered for the most tremendous storm of wind and snow from the east which has been experienced in this country during, perhaps, the present century. This had the natural effect of driving every thing before it. The Wild Fowl on this occasion were no exception, blowing them into our river and creeks for shelter in every direction. On the weather calming down, a pair of Smews were seen; one of them, a female, was shot. After a few hours rest, all 
the wild fowl departed, and the vessels again began to sail, our river resuming its normal condition.

A beautiful male Smew was shot on one of our island marshes a few years previously.

\section{RED-BREASTED MERGanser.}

Mergus serrator, Linn.

The Red-breasted Merganser is not uncommon, it comes into our creeks on the Medway whenever the weather is cold enough, it appears to be partial to the creeks, never flying by choice over the land, has been in many instances shot, fine handsome adult males, also females, but the young are the most numerous.

\section{GOOSANDER.}

Mergus merganser, Linn.

I only know of one instance of the Goosander coming on the Medway; an immature bird was shot while flying at some height over our saltines in winter time a few years ago.

\section{Great Crested Grebe. \\ Podiceps cristatus (Linn.).}

The Great Crested Grebe make its appearance singly nearly every winter on our creeks. They are 
somewhat difficult to shoot owing to their diving powers, but are now and then obtained.

\section{RED-NECKED GREBE. \\ Podiceps griseigena (Bodd.).}

The red-necked Grebe comes into our creeks at uncertain intervals in winter time or early spring, a few specimens have been obtained.

\section{Sclavonian Grebe. \\ Podiceps auritus (Linn.).}

The Sclavonian Grebe comes in winter, is not very common, but perhaps more so than all the rest of the Grebes, excepting the little Grebe or Dabchick; and it appears to frequent the open river in preference to the creeks.

EARed Grebe.

Podiceps nigricollis, Brehm.

I have only known of a single pair of Eared Grebes being shot, both immature, in the month of September, I88I. They are certainly the most rare of all the Grebes on the Medway. 


\section{LitTLE GREBE.}

\section{Podiceps fluviatilis (Tunstall).}

The Little Grebe is more numerous than all the rest of the Grebes put together; it goes by the name of the Dabchick, frequents our marsh ditches in summer, on the borders of which it breeds, always on the water adjoining a bunch of rushes or solitary bush or other such like shelter, builds a compact nest of wet herbage ; the eggs are never left exposed, being concealed from view by the parent on leaving her nest. In winter the Dabchick with us is more scarce and but seldom seen.

\section{Great Northern Diver.}

Colymbus glacialis (Linn.).

Young, immature Great Northern Divers are sometimes met with and shot on the Medway.

\section{Black-throated Diver.}

Colymbus arcticus, Linn.

Immature Black-throated Divers are also, like the previous species, occasionally met with and shot on our river. 
Rei-THRoated Diver.

Colymbus septentrionalis, Linn.

The red-throated Diver, locally called Sprat Loon, is common on the Medway, observed in the winter and spring with speckled back and white throat, most numerous in the month of March. I once happened to shoot a Sprat Loon from a boat, the day was clear, the tide low, the water smooth as glass. After falling it dived out of sight, then protruding its beak only above water for air floated and dived away.

\section{GUILLEMOT. \\ Uria troile (Linn.).}

The Guillemot is not very common on the Medway, come it does at intervals and is sometimes shot.

\section{Black Guillemot.}

$$
\text { Uria grylle (Linn.). }
$$

I am not aware that the Black Guillemot has ever appeared on the Medway.

\section{Little Auk. Mergulus alle (Linn.).}

A storm-driven specimen of the Little Auk may have occurred on or near the Medway. 


\section{PUFFIn.}

\section{Fratercula arctica (Linn.).}

The Puffin is extremely rare on the Medway, I only know of two being shot. A storm driven Puffin was picked up dead on our marsh after the November gale of 1893 .

\section{RAZOR-BILL. \\ Alca torda, Linn.}

The Razor-bill has not to my knowledge occurred on the Medway; it may possibly have done so following the track of the Guillemot.

\section{CORMORANT.}

\section{Phalacrocorax carbo (Linn.).}

It is only since the last five or six years that the Cormorant has become plentiful on our river; it may be that they are getting more numerous round the coast. They do not appear to be intimidated by the sight of the many vessels sailing to and fro all day and night, as they constantly fly past them and sometimes get shot. 


\section{SHAG.}

Phalacrocorax graculus (Linn.).

The Shag, or Lesser Cormorant has to my knowledge been observed on the Medway and shot on one or two occasions.

\section{Gannet.}

Sula Bassana (Linn.).

Our river affords no resting place for the Gannet, which scarcely ever comes beyond the line of vessels. A few years ago a Gannet was found near the centre of our wood. A flock of Rooks were seen by a labourer circling round and cawing vociferously over the spot where a dead Gannet was discovered which had evidently been storm-driven.

\section{Caspian TERn.}

Sterna caspia, Pall.

Some few years ago, before the river became so thickly studded with vessels, I had the pleasure one autumn of meeting with the Caspian Tern; it frequented a wide part of the Medway, and an adjoining wide creek for about a fortnight; happening to shoot a Common Tern from my yacht, the great bird came, hovered for a second or two over it, but from the distance the little bird had floated, I was unable to procure the Caspian Tern. 


\section{SANDWICH TERN.}

Sterna cantiaca, Gmel.

The Sandwich Tern is but seldom seen on the Medway. It comes in the autumn when a few immature specimens have been shot.

\section{COMMON TERN.}

Sterna fluviatilis, Naum.

This is the Common Tern or Sea Swallow of the Medway; provided the season is favourable they sport on the calm water in the autumn for a fortnight at least, their graceful pitching and rapid flight is always pleasing to see.

\section{ARCTIC TERN.}

Sterna macrura, Naum.

I have never been able to recognise the Arctic Tern among the many common Terns that sometimes visit our river ; in the autumn possibly they may have occurred, but have not to my knowledge been shot.

LESSER TERn.

Sterna minuta, Linn.

The Lesser Tern is not uncommon on the Medway. 
In the month of August, at which time of year I have generally met with them, they visit our creeks in small numbers.

\section{BLACK TERN.}

\section{Hydrochelidon nigra (Linn.).}

Like the Lesser Tern, the Black Tern visits us in the month of August; I have met with them sitting upon the buoys on the Medway, and never in any other place, always immature.

\section{LitTle Gull.}

Larus minutus, Pall.

February 7 th, I870, I had the pleasure of meeting with and shooting the Little Gull flying over a plough field bordering a marsh, when it was blowing a strong wind from the east, it was in the second year's plumage; in March I saw another Little Gull with a black head accompanying a flock of the Common Black-headed Gulls up a creek, it separated and flew towards and over a flock of sheep that were grazing on a marsh bank.

February I4th, I874, an adult Little Gull was shot at the mouth of Milton Creek.

September I7th, I884, a young immature Little Gull was shot in mottled plumage on our river. 


\section{BLACK-HEADED GULL.}

Larus ridibundus, Linn.

The Black-headed Gull is common enough on the Medway in the autumn, winter, and early spring, and when they begin to assume their black heads they depart; visit our sprat fields, coming by hundreds; should the weather be cold they follow the waggons from the wharf into the field; only by continually shooting are they kept away, they wait in an adjoining field at a little distance in the line of scent, watching an opportunity in order to pick up a few sprats in an unprotected corner; should the gunner be absent for a few minutes down they come ready to carry all the sprats away; when evening arrives they retire to the river where they roost. The following day they repeat their excursions to the sprat field, stealing some if they can till the sprats are all ploughed in. Should a frost intervene to stop the plough the Gulls are again on the alert, not losing a chance all the time a sprat is to be had. The Black-headed Gull in rough weather often visits the fresh turned ploughed furrows, following the plough across the field, frequently in company with rooks, robbing the land of the earth-worms.

KitTIWAKE.

Rissa tridactyla (Linn.).

The Kittiwake is rather a rare straggler on the Medway and seldom met with. The few that are 
shot are generally immature birds; incidentally an adult may be shot on the river or flying over the land.

\section{COMMON GuLL.}

Larus canus, Linn.

The Common Gull is of frequent occurrence on the Medway; they are pretty generally distributed, more particularly where food is to be had, it never comes inland.

\section{Lesser BlaCK-BACKed Gull.}

Larus fuscus, Linn.

The Lesser Black-backed Gull comes on the Medway in small numbers, flies high, therefore the black back and white breast is plainly distinguished at a distance; the immature, with brown mottled plumage, are often shot.

\section{HERRING GULL.}

Larus argentatus, Gmel.

The Herring Gull flies over the land at the time of the sprat season and makes familiar acquaintance with the Black-headed Gull ; like them it follows the waggons from the wharf into the field, keeping them company all the while the sprats are exposed, they are not so numerous as the black-heads by about 30 
to $\mathrm{I}$; in every respect they continue with each other until the coast is cleared and the sprats all covered in by the plough.

\section{Great Black-Backed Gull. \\ Larus marinus, Linn.}

The great amount of traffic on the Medway keeps the Great Black-backed Gull at a distance ; they do not like the noise and bustle, therefore make themselves scarce; are sometimes shot, most often in immature plumage.

\section{Great SkUA.}

Stercorarius catarrhactes (Linn.).

The Great Skua has not to my knowledge ever appeared on the Medway.

\section{Pomerine SKUA.}

Stercorarius pomatorhinus (Temm.).

I must extend the bounds of my district in order to include a pair of Pomerine Skuas, which were shot by a bargeman when in the act of killing a Common Gull, beyond Rochester bridge, the 20th February, I882, one a fine adult with yellow collar and a long turned up tail, the other immature, in the brown plumage. A Pomerine Skua was shot flying 
over Chatham Hill in windy weather, November 27 th, 1890 , either in the second or third year's plumage.

\section{Arctic Skua.}

Stercorarius crepidatus (Gmel.).

The Arctic Skua is of frequent occurrence on the Medway in the months of September and October; they are seen chasing the Common Tern and the Black-headed Gull ; they are always in the immature plumage, the colour which prevails is a dark chocolate brown. Only on one occasion has another variety been met with, which is spotted sandy and brown. The mature bird with a long tail is extremely scarce, one was shot out of the bounds of my district, October, I865, on the Swale River.

\section{Long-TAILED SkUa.}

Stercorarius parasiticus (Linn.).

I have heard of no specimen of the Long-tailed Skua ever having been shot on the Medway.

Fulmar Petrel.

Fulmarus glacialis (Linn.).

Exactly the same may be said of the Fulmar Petrel, which I believe has never been seen on the Medway. 


\section{Forked-TAiled Petrel. \\ Cymochorea leucorrhoa (Vieill.).}

The Forked-tailed Petrel has occurred at least on one occasion in the neighbourhood of the Medway.

\section{Stormy Petrel. \\ Procellaria pelagica, Linn.}

A Shepherd's boy hearing a squeaking in the air at the same time descending from some height, picked up a Stormy Petrel alive.

THE END. 


\section{N D E X.}

Auk, Little, 79.

Avocet, 62.

\section{Bittern, 57 .}

Blackbird, 2 r.

Blackcap, 25.

Brambling, 36 .

Bramble Finch, 36 .

Bullfinch, 40.

Bunting, Black-headed, 35 . Cirl, 35 . Corn, 34 . Snow, 34. Yellow, 35 .

Buzzard, Common, I3. Honey, 14. Rough-legged, 14.

Chaffinch, 36.

Chiffchaff, 27.

Coot, 68.

Cormorant, 8o.

Creeper, 46.

Crossbill, 4I.

Crow, 42. Grey, 42.

Cuckoo, 47.

Curlew, 59.

Diver, Black-throated, 78 . Great Northern, 78 .
Diver, Red-throated, 79.

Dotterel, 55.

Dove, Ring-, 52.

- Stock-, 52. Turtle, 52.

Duck, Eider, 73.

— Golden-eyed, 75.

— Long-tailed, 75 .

- Scaup, 74 .

— Tufted, 74 .

— Wild, 7 r.

Dunlin, 66.

Eagle. Sea, 9 .

Eider Duck, 73.

Falcon, Peregrine, ro.

Fieldfare, 20.

Firecrest, 28.

Flycatcher, Pied, 19.

- Spotted, 18.

Gadwall, 7r.

Gannet, 8r.

Garden Warbler, 25.

Gargany, 7r.

Geese, 69.

Godwit, Black-tailed, 62.

— Bar-tailed, 63.

Goldcrest, 27.

Goldeneye, 75 . 
Goldfinch, 38 .

Goosander, 76 .

Goose, Brent, 69.

Grasshopper Warbler, 24.

Greenfinch, 38.

Grebe, Eared, 77.

— Great Crested, 76.

— Little, 78.

- Red-necked, 77.

- Sclavonian, 77.

Guillemot, 79.

— Black, 79.

Gull, Black-headed, 84 .

- Common, 85.

- Great Black-backed, 86.

- Herring, 85 .

- Kittiwake, 84 .

- Lesser Black-backed, 85 .

- Little, 83 .

Harrier, Ash-coloured, I5.

- Hen, 15.

- Marsh, i 5 .

- Montagu's, 15.

Hawfinch, 38.

Heron, 57.

- Purple, 57.

Hobby, II.

Hoopoe, 47.

Jackdaw, 43 .

Jay, 44 .

Kestrel, I2. Lesser, I 2.

Kingfisher, 48.

Kittiwake, 84 .

Knot, 65 .

Landrail, 67.

Lapwing, 56.

Lark, Sky-, 33.

- Wood-, 34 .
Linnet, 40.

Magpie, 44.

Mallard, 7I.

Martin, 50.

- Sand, 50.

Merganser, 76 .

Merlin, II.

Moorhen, 68.

Nightjar, 5I.

Nightingale, 22.

Nuthatch, 47.

Osprey, 10.

Owl, Barn, I7.

— Long-eared, I6.

Short-eared, 16.

Oyster-catcher, 57 .

Pallas' Sand-Grouse, 53.

Partridge, 53.

—_ Red-legged, 54 .

Peewit, 56.

Petrel, Forked-tailed, 88.

- Fulmar, 87.

- Stormy, 88.

Phalarope, Grey, 67. Red-necked, 66.

Pheasant, 53.

Pintail Duck, 7 I.

Pipit, Meadow, 32.

- Red-throated, 32. Richard's, 33 .

- Rock, 32. Tree, 3 I.

Plover, Golden, 55 .

- Great, 54 .

- Grey, 56.

— Norfolk, 54 .

- Ringed, 55 .

Pochard, 74.

Puffin, 8o. 
Quail, 54.

Rail, Land-, 67.

— Spotted, 67. Water, 68.

Raven, 42.

Razor-bill, 80.

Redpoll, 39.

Redshank, 60. Spotted, 60.

Redstart, 22.

- Black, 22.

Redwing, 20.

Reed Warbler, 25.

Ring-Dove, 52.

Ring Ouzel, 21.

Robin, 22.

Roller, 48.

Rook, 43.

Ruff, 62.

Sand-Grouse, 53 .

Sandpiper, Common, 6 I.

Curlew, 64 .

Green, 60.

Purple, 66.

Wood, 6r.

Scaup, 74.

Scoter, Common, 74. Velvet, 73.

Sea Eagle, 9.

Sedge Warbler, 24.

Shag, 8I.

Sheldrake, 70.

Shoveller, 70.

Shrike, Great Grey, I 7. Red-backed, I8. Woodchat, I8.

Siskin, 39.

Skua Arctic, 87.

- Great, 86.

Long-tailed, 87

Pomerine, 86.
Skylark, 33.

Smew, 75 .

Snakebird, 46.

Snipe, Common, 64 .

- Great, 63.

- Jack, 64 .

Sparrow, Hedge, 2 I.

- House, 37. Tree, 37.

Sparrow Hawk, I3.

Spoonbill, $5^{8}$.

Starling, 4I.

The Rose Coloured, 42.

Stint, Little, 65 . Temminck's, 65.

Stock-Dove, 52.

Stonechat, 23.

Stork, Black, 58 .

Swallow, 49.

Swan, Bewick's, 70. Wild, 69.

Swift, 50.

Teal, 73 .

Tern, Arctic, 82.

— Black, 83.

- Caspian, 8r.

Common, 82.

- Lesser, 82. Sandwich, 82.

Thrush, Missel, 19.

- Song, 19.

Tit, Bearded, 30.

- Blue, 28.

- Cole, 29.

Great, 28.

Long-tailed, 29.

Marsh, 29.

Tree-creeper, 46.

Twite, 40.

Turnstone, 56.

Turtle Dove, 52. 
Wagtail, Grey, 3 I.

$$
\text { Pied, } 30 .
$$

- Yellow, 31.

Warbler, Blackcap, 25.

- Garden, 25.

- Grasshopper, 24.

- Reed, 25. Sedge, 24.

Willow, 27. Wood, 26.

Waxwing, 30.

Wheatear, 24.

Whimbrel, 59.

Whinchat, 23.

Whitethroat, 26.

— Lesser, 26.
Wigeon, 73 .

Woodcock, 63.

Wood Lark, 34 .

- Pigeon, 52.

Warbler, 26.

Woodpecker, Green, 45. Great Spotted, 45. Lesser, 45.

Wren, 46.

—- Fire-crested, 28. Gold-crested, 27. Willow, 27.

Wryneck, 46.

Wydah Finch, 39.

Yellowammer, 35 . 


\section{BOOKS OF LOCAL OBSERVATION}

ON BIRDS.

The Birds of Lancashire. By F. S. Mrtchell. Second Edition. Revised and Annotated by HowArD SAUNDERS, F.L.S. \&c., with additions by R. J. HowARD, and other local authorities. 297 pages, demy 8vo, with map and 12 illustrations, Ios. 6d.

The Birds of East Kent, A Tabulated List and Description of, with Anecdotes and an Account of their Haunts. By George Dowker, F.G.S. $8 \mathrm{vo}$, sewed, 2s. $6 \mathrm{~d}$.

The Birds of Middlesex. By J. E. Harting. Post 8vo, 7s. 6d.

The Birds of Somersetshire. By Cecrl Smith. Post 8vo, 7s. 6d.

The Birds of Norfolk. By the late Henry Stevenson. Completed by Thomas Southwell. 3 vols. 8 vo, £I IIs. $6 \mathrm{~d}$.

The Birds of the Humber District. By John Cordeaux. Post 8 vo, 6s.

The Birds of Suffolk. By ChURCHILl BabINGTON, D.D., V.P.R.S.L., \&c. 8vo, cloth, Ios. 6d.

Bird-Life of the Borders : Records of Wild Sport and Natural History on Moorland and Sea. By Abel Chapman. With numerous Illustrations by the Author. $8 \mathrm{vo}, 12 \mathrm{~s} .6 \mathrm{~d}$.

The Birds of Jamaica. By P. H. Gosse. Post 8 vo, ros.

The Birds of Egypt. By Captain G. E. Shelley, F.Z.S., \&c. Royal 8vo., Coloured Plates, ŁI I Is. 6d.

The Birds of Damara-Land and Adjacent Countries of South-West Africa. By the late C. J. ANDERsson. Arranged and edited, with Notes by John Henry Gurney. 8vo, Ios. 6d.

The Birds of Rainham, including the District between Chatham and Sittingbourne. By Walter Prentrs. Post 8 vo.

GURNEY \& JACKSON, I, Paternoster Row. (MR. VAN VOORST'S SUCCESSORS.) 


\section{OTHER BOOKS ABOUT BIRDS}

PUBLISHED BY

\section{GURNEY AND JACKSON.}

A History of British Birds. By the late WM. YARRELL, V.P.L.S., F.Z.S. Fourth Edition, revised to the end of the Second Volume by Professor NewTon, M.A., F.R.S. The revision continued by Howard Saunders, F.L.S. 4 vols. 8 vo, cloth, with 564 Illustrations, £4.

"The Fourth Edition of 'Yarrell' will remain for many years a classic without a rival."-Academy.

The Fowler in Ireland: or, Notes on the Haunts and Habits of Wild Fowl and Sea Fowl, including Instructions in the Art of Shooting and Capturing them. By Sir Ralph Payne-Gallwey, Bart. With many Illustrations of Fowling, Birds, Boats, Guns, and Implements. 8vo, £I Is.

The Book of Duck Decoys, their Construction, Management, and History. By Sir Ralph Payne-Gallwey, Bart. Crown 4to, cloth, with coloured Plates, Plans, and Woodcuts, £I $5 \mathrm{~s}$.

Notes on Sport and Ornithology. By His Imperial and Royal Highness the late Crown Prince Rudolf of Austria. Translated, with the Author's permission, by C. G. DANFord. Demy 8 vo, 650 pages, with an Etching by Frank SHORT, I8s.

Wild Spain. By Abel Chapman and Walter J. Buck. 8vo, with I74 Illustrations, $£$ I Is.

"The book is a prize to all who are interested in Spain, or in the pursuit and study of wild game. To read it is to be smitten with the desire to seek out the flamingo in the marshes, the bustard and the wild hoar in the cornlands and cork-oak thickets, the ibex and the lammergeier in the high Sierras."National Observer.

A Handbook of British Birds. Showing the Distribution of the Resident and Migratory Birds in the British Islands, with an Index to the Records of the Rarer Specimens. By J. E. HARTING, F.L.S , \&c. 8vo, 7s. 6d.

Hints on Shore-Shooting, including a Chapter on Skinning and Preserving Birds. By J. E. Harting, F.L.S. Post 8vo, 3s. 6d.

A List of British Birds. Compiled by a Committee of the British Ornithologists' Union. 8vo, sewed, ros. 6d.

A List of British Birds. Second Thousand. Revised by HowARD SAUNDERS, F.L.S., F.Z.S., \&c. For labelling Specimens or for Reference. 8vo, sewed, 6d.

\section{GURNEY \& JACKSON, I, Paternoster Row.} (MR. VAN VOORST'S SUCCESSORS.) 
In One Volume, $75^{\circ}$ pages, demy $8 \mathrm{vo}$, cloth, with 367 fine Woodcuts and 3 Maps, $\mathcal{E}_{\mathrm{I}}$ Is.

\section{AN \\ ILLUSTRATED MANUAL}

$\mathrm{OF}$

\section{BRITISH BIRDS.}

BY HOWARD SAUNDERS, F.L.S., F.Z.S., \&c.

Editor of the Third and Fourth Volumes of the Fourth Edition of "Yarrell's History of British Birds."

"It would be difficult to give a better condensation of facts in fewer lines than has been contrived by $\mathrm{Mr}$. Saunders."-Zoologist.

"Perhaps the question most frequently put to a zoologist by a lay friend is, "What is a really good book on British Birds that is not too expensive?' and the question has been one that has been found extremely difficult to answer. Mr. Saunders deserves our thanks for having taken this difficulty out of our way."-Athenceum.

"Excellent alike in style and matter, it ought to be in the hands of every lover of birds, and should take the place of several inferior books on the subject now before the public."-Annals of Natural History.

"It is scarcely necessary to inform those who are acquainted with the previous work of the author, that the information is not only valuable from its correctness, but that it is brought up to the present date."--Field.

GURNEY \& JACKSON, I, Paternoster Row. (MR. VAN VOORST'S SUCCESSORS.) 


\section{STANDARD WORKS}

ON

\section{BRITISH NATURAL HISTORY.}

The Natural History and Antiquities of Selborne. By the late Rev. Gilber'T White. Edited by Thomas Bell, F.R.S., \&c. 2 vols. 8vo, with Steel-plate and other Illustrations, $£$ I I Is. $6 \mathrm{~d}$. (A few copies large paper, royal $8 \mathrm{vo}$, with the Plates on India Paper, £3 3s.)

A History of British Quadrupeds; including the Cetacea. By Professor BELL, F.R.S., \&c. Second Edition, revised and partly rewritten by the Author, assisted by R. F. Tomes and E. R. Alston. 8vo, illustrated by 160 Woodcuts, $£ \mathrm{I}$ 6s.

History of British Reptiles. By Professor BeLl. Second Edition, with 50 Illustrations, I $2 \mathrm{~s}$.

Yarrell's History of British Fishes. Third Edition, with Figures and Description of the additional Species by Sir JoHN RICHARDson, C.B., and with a Portrait and Memoir. 2 vols. 8 vo, 522 Illustrations, $£ 33$ s.

History of British Stalk-Eyed Crustacea (Lobsters, Crabs, Prawns, Shrimps, \&c.). By Professor Bel.t. Illustrated by 174 Engravings. $8 \mathrm{vo}, £ \mathrm{I} 5 \mathrm{~s}$.

History of British Sessile-Eyed Crustacea (Sandhoppers, \&c.). By C. Spence Bate, F.L.S., and J. O. Westwood, F.L.S., \&c. Many Illustrations. 2 vols. 8 vo, $£ 3$.

History of British Mollusca and their Shells. By Professor EDWARD Forbes, F.R.S., \&c., and Sylvanus HaNLey, B.A., F.L.S. Illustrated by 203 copper-plates, 4 vols. 8 vo, $£ 6$ 10s.; royal 8vo, with the Plates Coloured, $£ \mathrm{I} 3$.

A History of the British Hydroid Zoophytes. By the Rev. Thomas Hincks, B.A. 2 vols. 8vo, cloth, with 67 Plates, $£ 22$ s.

History of the British Zoophytes. By GEORGE JoHnston, M.D., LL.D. Second Edition, in 2 vols. 8vo, £2 2s.

History of British Starfishes and other Animals of the Class Echinodermata. By Professor EDWARD Forbes. 8vo, I20 Illustrations, $15 \mathrm{~s}$.

A History of the British Marine Polyzoa. By the Rev. Thomas Hincks, B.A., F.R.S. With Plates, giving Figures of the Species and principal Varieties. 2 vols. demy 8 vo, $£ 33$ s.

GURNEY \& JACKSON, I, Paternoster Row. (MR. VAN VOORST'S SUCCESSORS.) 
An Invasion of Rooks.

At the last meeting of the British Ornithologists' Club one of the members, Mr. Griffith, remarked that on getting out of the train at Orpington Station, Kent, about 4.20 in the afternoon of November 14 he saw an extraordinary flight of rooks passing in a steady, continuous stream for $16 \frac{1}{2}$ minutes, apparently making for Farnborough. They were winging the way in a great column of from fifteen to twenty abreast, and were moving at about ten miles an hour. On the lowest estimate he reckoned that about 13,000 passed over him, but how many had already passed before he stepped out of the railway station he could not, of course, say, but they stretched away southwards as far as the eye could see. Whether these were native birds which had been on a foraging expedition and were returning to their roosting trees or whether this great army were aliens come to take up their quarters here it would be difficult to say. If they were native-bred birds then such a gathering must have some hidden significance, for gathering on such a grand scale are unprecedented.

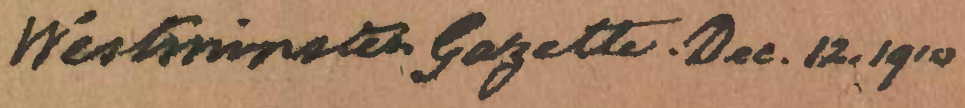





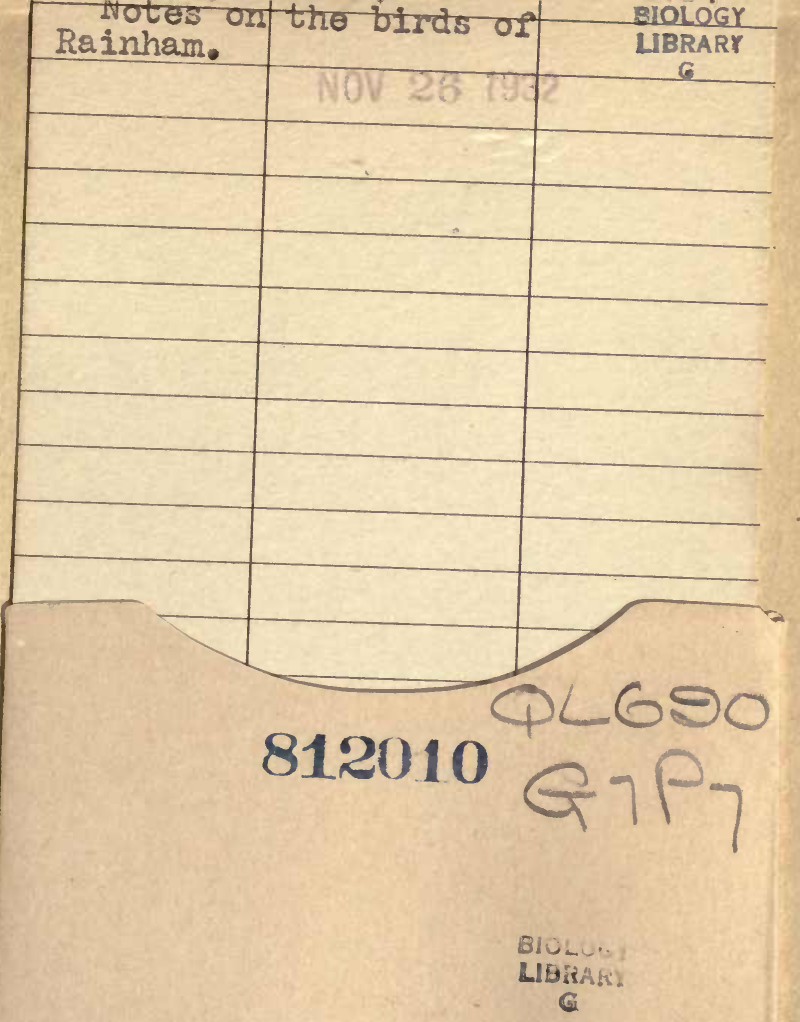

UNIVERSITY OF CALIFORNIA LIBRARY 
